\title{
A formação continuada de professores de Educação Física a partir de um espaço coletivo escolar: uma experiência no Brasil
}

La formación continua de profesores de Educación Física desde un espacio escolar colectivo: una experiencia en Brasil

The continuing education of Physical Education teachers from a collective school space: an experience in Brazil

Volumen 21, Número 2

Mayo - Agosto

pp. 1-31

DijnaneVedovatto

Marília Rubino

\section{Citar este documento según modelo APA}

Vedovatto, Dijnane., y Rubino, Marília. (2021). A formação continuada de professores de

Educação Física a partir de um espaço coletivo escolar: uma experiência no Brasil. Revista Actualidades Investigativas en Educación, 21(2), 1-31. Doi. 10.15517/aie.v21i2.46780 


\title{
A formação continuada de professores de Educação Física a partir de um espaço coletivo escolar: uma experiência no Brasil
}

La formación continua de profesores de Educación Física desde un espacio escolar colectivo: una experiencia en Brasil

The continuing education of Physical Education teachers from a collective school space: an experience in Brazil

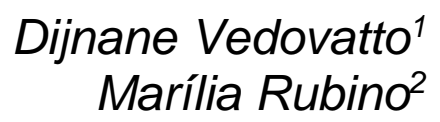

\begin{abstract}
Resumo: A prática docente exige diversos saberes, que não se esgotam na formação inicial, isso foi percebido por meio da experiência de uma das autoras ao iniciar a carreira docente, levantando muitos questionamentos, que desencadearam em uma pesquisa de mestrado profissional em educação sobre a temática. Assim, a formação continuada é de grande importância para a prática profissional, tendo como desafio abordagens baseadas na realidade dos professores. Este artigo teve como objetivo identificar e analisar os processos formativos no local de trabalho realizado dentro do Horário de Trabalho Pedagógico Coletivo - HTPC, da área específica de Educação Física, ofertado pela Secretaria Municipal de Educação do interior do estado de São Paulo, bem como investigar as percepções de 30 professores e uma coordenadora sobre possíveis influências destes processos formativos no exercício da docência. Tal pesquisa é de natureza qualitativa, possui características de estudo de caso, tendo como instrumentos da coleta de dados a análise documental, questionários e entrevista semi estruturada. Apresenta como orientação teórica a literatura que fundamenta a discussão sobre a aprendizagem e desenvolvimento profissional da docência, na perspectiva da profissionalização do ensino. Os resultados indicam que as ações desenvolvidas no HTPC promovem diversos saberes que contribuem para os múltiplos desafios da prática pedagógica, uma vez que a proposta do HTPC prevê estreita relação com a prática dos professores, bem como um protagonismo, o que gera um movimento de constante reflexão entre a prática desenvolvida nas escolas, e a formação continuada no HTPC. A criação e manutenção do HTPC em questão permitiu significativo desenvolvimento profissional, o que contribuiu para o trabalho docente nas escolas, e para o processo de profissionalização do ensino.
\end{abstract}

Palavras chave: formação de docentes, educação permanente, horário escolar.

Resumen: La práctica docente requiere de varios tipos de conocimientos, los cuales no se limitan a la formación inicial, esto se percibió a través de la experiencia de una de las autoras al iniciar su carrera docente, suscitando múltiples interrogantes, que desencadenaron una investigación de maestría profesional en educación sobre el tema. Así, la formación continua es de gran importancia para la práctica profesional, con el desafío de planteamientos basados en la realidad de los docentes. Este artítculo tiene como objetivo identificar y analizar los procesos formativos en el lugar de trabajo realizados dentro del Horario de Trabajo Pedagógico Colectivo (HTPC), en el área específica de la educación física, así como investigar las percepciones de 30 docentes y una coordinadora sobre la posible influencia de estos procesos formativos en el ejercicio de la docencia. Esta investigación es de carácter cualitativo, estudio de caso y utiliza el análisis documental, cuestionarios y entrevistas semiestructuradas. Presenta, como guía teórica, la literatura en la cual se basa la discusión sobre el aprendizaje y el desarrollo profesional de la docencia desde la perspectiva de la profesionalización docente. Los resultados indican que las acciones llevadas a cabo en el HTPC promueven conocimientos diversos que contribuyen a los múltiples desafíos de la práctica pedagógica, ya que la propuesta del HTPC prevé una estrecha relación con la actividad docente, así como un rol de prevalencia, lo que genera un movimiento de reflexión constante entre la práctica desarrollada en las escuelas y la formación continua dentro del HTPC. La creación y el mantenimiento de dicho HTPC ha permitido un importante desarrollo profesional, lo que ha contribuido al ejercicio de la docencia en las escuelas y al proceso de profesionalización de la enseñanza.

Palabras clave: formación de docentes, educación permanente, horario escolar.

1 Universidade Federal de São Carlos, São Paulo, Brasil. Dirección electrónica:

Dijnane@ufscar.br Orcid https://orcid.org/0000-0002-7435-6849

2 Universidade Federal de São Carlos, São Paulo, Brasil. Dirección electrónica: mariliarubino@gmail.com Orcid https://orcid.org/0000-0003-0911-7494

Artículo recibido: 18 de noviembre, 2020

Enviado a corrección: 10 de marzo, 2021

Aprobado: 19 de abril, 2021

Los contenidos de este artículo están bajo una licencia Creative Commons 


\begin{abstract}
Teaching practice requires several types of knowledge, which are not limited to initial training, this was perceived through the experience of one of the authors when beginning her teaching career, raising many questions, which triggered a professional master's research in education on the subject. Thus, continuing education is of great importance for professional practice, with the challenge of approaches based on the reality of teachers. This article had the objective to identify and analyse the formative processes at the workplace performed within the Collective Pedagogic Working Hours (CPWC) in the area of Physical Education in Piracicaba - Brazil. We focus on the perceptions of 30 teachers and one pedagogical coordinator about the influences of these formative processes in the teaching practice. This qualitative study can be characterised as a case study, which utilised data collected through documental analysis, questionnaires and semi-structured interviews. The theoretical background is the literature on learning and professional development of teachers, from the perspective of the professionalization of teaching. The results indicate that the activities developed in the CPWC have strong relationship with the challenges of the pedagogical practice of the teachers and values teacher's perspectives. The formative practices within the program promotes an iterative reflexive process of the pedagogical interventions developed by teachers and also their participation in the CPWC initiative. Thus, the study suggests that the creation and development of the CPWC contributes to the collective construction and participation of teachers in their formative processes, with positive implications for teaching professionalisation.
\end{abstract}

Keywords: teacher training, permanent education, school timetable.

\title{
1. Introdução
}

O objetivo deste trabalho foi investigar a estrutura, organização e desenvolvimento do espaço-tempo dos Horários de Trabalho Pedagógico Coletivo (HTPC) da área da Educação Física de uma rede municipal de ensino do interior do estado de São Paulo, visando identificar as possíveis apropriações dos processos formativos presentes no HTPC para o exercício docente.

A gestão da sala de aula, tarefa que é de responsabilidade do professor por excelência, exige o contato com situações complexas e singulares, cuja solução nem sempre é dada a priori, mas que requerem respostas imediatas. O professor precisa dominar certas competências e saberes para agir individual e coletivamente, a fim de fazer face às especificidades de seu trabalho. A prática profissional é considerada uma instância de "produção" de saberes e competências (Tardif, 2012).

Em vários países, parte dos professores trabalha em condições extremamente difíceis, ocasionando um "desgaste moral, um sentimento de impotência ou de fracasso acompanhado de uma falta de reconhecimento ou até mesmo de uma desvalorização profissional, que conduz a um desânimo em face de sua tarefa e uma impressão de inutilidade social" (Tardif, 2013, p. 567). Tal sentimento acontece em grande parte devido a mudanças tecnológicas, políticas e sociais que marcaram o mundo a partir da década de 1990, junto com inovações trazidas pela globalização e o neoliberalismo, que repercutiram na educação (Gatti, 2010; Maués, 2003).

Com o objetivo de integrar a escola no novo mercado educacional global, regido pela concorrência entre as instituições públicas e privadas, pela sistematização da avaliação 
padronizada dos componentes do sistema educativo, pela definição de objetivos curriculares normatizados e comparáveis, pela defesa da livre escolha dos pais, e pela autonomia das instituições escolares em um ambiente institucional descentralizado, o Estado apresenta uma nova concepção do seu papel na gestão dos serviços públicos de educação, baseado em resultados (Tardif, 2013). Segundo o autor, esta situação responsabiliza os professores pelo sucesso escolar de seus alunos, mensurável por meio de testes padronizados e de comparações com outros professores e outras instituições, tanto no nível nacional quanto internacional.

Scheibe (2010) assinala que as pesquisas sobre a profissão docente revelam uma série de problemas e desafios para a elevação do status socioeconômico da categoria: os baixos salários predominantes e a deterioração das condições de trabalho decorrente das longas jornadas, salas superlotadas, aumento da indisciplina e da violência na escola, dificuldade em realizar atualizações de conteúdo e metodológicas, as cobranças de maior desempenho profissional, entre outros. A autora complementa que as carreiras não oferecem clareza de percurso, e o imaginário coletivo está extremamente desmotivado em relação à profissão.

Oliveira (2004) relata que nos aspectos que dizem respeito às relações de emprego dos professores, o aumento dos contratos temporários nas redes públicas de ensino, a falta do respeito a um piso salarial nacional, a inadequação ou mesmo ausência, em alguns casos, de planos de cargos e salários, a perda de garantias trabalhistas e previdenciárias, têm tornado cada vez mais agudo o quadro de instabilidade e precariedade do emprego no magistério público. Podemos acrescentar a estes fatores a desilusão em relação à profissão, o que nos mostra que a profissão docente está passando por uma crise. (Lapo e Bueno, 2003; Sampaio e Marin, 2004).

O Programme for International Student Assentment (PISA), a Avaliação Nacional do Rendimento Escolar - ANREsc (também denominada "Prova Brasil"), a Avaliação Nacional da Alfabetização (ANA) são exemplos de testes avaliativos, sendo o primeiro realizado pela OCDE, e os dois últimos parte do SAEB, o Sistema Nacional de Avaliação da Educação Básica no Brasil. Segundo o INEP (Instituto Nacional de Estudos e Pesquisa em Educação Anísio Teixeira), o SAEB tem como principal objetivo promover um diagnóstico da educação básica brasileira, bem como sobre alguns fatores referentes ao desempenho do estudante, fornecendo um indicativo sobre a qualidade do ensino ofertado. O referido levantamento produz informações que podem subsidiar a (re) formulação, e o monitoramento das políticas públicas, com vistas a contribuir para a melhoria da qualidade do ensino. 
O PISA tem o intuito de situar o desempenho dos alunos brasileiros no contexto da realidade educacional internacional, além de possibilitar o acompanhamento das discussões sobre as áreas de conhecimento avaliadas pelo Pisa em fóruns internacionais de especialistas (INEP)

Fröhlich (2010), em sua pesquisa sobre políticas públicas de formação continuada de docentes, relata que os últimos resultados negativos que o Brasil apresentou em avaliações de rendimento em educação nacional, e também os baixos resultados que o país obteve nas avaliações internacionais como o PISA, retratam a fragilidade e ineficiência da educação básica, evidenciando a falência do sistema educacional do país. Tardif (2013) complementa que muitas vezes se atribui o fracasso dos alunos aos professores. Segundo o autor, se os alunos fracassam, seria em função da ineficácia dos professores, ou em função do seu insuficiente rendimento, ou porque não utilizam as boas práticas.

Souza (2006, p. 484), em sua pesquisa sobre formação continuada e fracasso escolar, conceitua esta crítica como o "argumento da incompetência", no qual "a principal causa para a baixa qualidade do sistema educacional é, justamente, a incompetência dos professores". A mesma autora completa que alguns trabalhos acadêmicos contribuíram, mesmo sem ter este propósito, para uma visão negativa e homogênea do professor, considerado tecnicamente como incompetente e politicamente descompromissado. Os professores foram afetados pela "lógica perversa de ocultamento da realidade educacional subjacente ao argumento da incompetência" (Souza, 2006, p. 486). A autora defende que a escola precisa ser melhorada, e não somente o professor.

Heringer e Figueiredo (2010, p.84) nos atentam para um paradoxo existente, pois "a carga de responsabilidade vai da acusação e atribuição de culpa, ao reconhecimento da capacidade de solucionar problemas".

Contreras (2002) afirma que os professores estão submetidos a pressões e contradições das quais nem sempre é fácil se livrar ou que mal são captadas com lucidez. Segundo ele, cada vez mais Ihe são atribuídas funções, acarretando um aumento das responsabilidades e do sentimento de culpa, quando, na verdade, os problemas que enfrentam são de ordem social, política e institucional.

Rossi e Hunger (2013) afirmam que o professor, por meio da precarização das condições de trabalho, de sua deslegitimação como produtor de saberes, da perda de poder aquisitivo e prestígio social, sofre desprofissionalização docente. 
Um aspecto que pode remeter à desvalorização docente se refere às ofertas e condições para a formação continuada de professores. Nesse sentido, ao observarmos a área da Educação Física, percebe-se lacunas, pois há um significativo numero de formações de curta duração, que se baseiam na transmissão de conhecimentos que acabam por não contribuir efetivamente para o desenvolvimento profissional do professor, sendo cogente pensar em outras ações de formação, no qual este tem participação efetiva na construção de políticas de formação continuada, haja valorização da escola como local de formação, e o ponto inicial desta formação continuada sejam as suas próprias práticas (Gunther e Molina Neto, 2000; Correia e Ferraz, 2010; Rossi, 2010; 2013; Loureiro e Caparróz, 2011).

Molina Neto (1997), ao analisar o programa de 15 eventos de formação continuada em Educação Física, chegou a quatro constatações: 1) A formação dos professores de Educação Física desenvolve-se a partir de modelos tecnicistas de transferência e aquisição de conhecimento; 2) A formação mais comum é o curso de 20 ou 40 horas, no âmbito das técnicas corporais, vinculado a modismos, e incentivados pelos meios de comunicação e pelas tradições da área; 3) As atividades de formação com objetivo de reflexão e produção do conhecimento têm espaços reduzidos; 4) No avançar do tempo de docência, o professor muda seu interesse de formação continuada pautada em atividades específicas e práticas, para atividades mais reflexivas, demonstrando a ineficácia de programas massivos e homogêneos de formação. O autor defende ser necessário pensar em uma formação pautada na reflexão, onde os professores de Educação Física são investigadores, e produtores de conhecimentos que Ihes permitam pesquisar autonomamente sua própria prática, concebendo e concretizando a escola como unidade de investigação e formação (Molina Neto, 1997).

Dentro dessa perspectiva, a profissionalização envolve um conjunto de conhecimentos, saberes, capacidades e competências que caracterizam a profissão docente (Nóvoa, 1995; Wittorski e Vieira, 2014). Um dos fatores que implicam na desvalorização da profissão docente reside em não considerar o professor como um produtor de saberes, de modo que o corpo docente é desvalorizado também em relação aos saberes que possui (Nóvoa, 1995; Tardif, 2012).

\section{Marco Teórico}

\subsection{A profissionalização docente}

A profissionalização se relaciona com a conquista de autonomia de uma profissão, a partir da responsabilização e controle do trabalho por parte dos profissionais, da criação de 
um código de ética que orienta as ações deste grupo de profissionais, do reconhecimento da relevância social e da complexidade do trabalho a ser realizado, de uma remuneração digna, do aprimoramento dos saberes que orientam a ação, além de maior exigência do nível de formação necessária para o ingresso e exercício profissional (Tardif, 2012; Tardif e Lessard, 2014; Wittorski e Vieira, 2014). É um processo de apropriação dos conhecimentos, dos saberes, das capacidades e competências que caracterizam uma profissão (Wittorski e Vieira, 2014). A profissionalização objetiva a elevação do status do professor, valorizar seu trabalho junto à opinião pública, aumentar sua autonomia, e também melhorar suas condições de trabalho (Tardif, 2013).

A profissionalização dos professores depende da construção de um corpo de conhecimentos que ultrapasse a esfera do instrumental, pois "em grande parte, a comunidade científico-educacional alimenta-se dos professores e legitima-se por meio de uma reflexão sobre eles" (Nóvoa, 1995, p. 15). Tal fato acaba por não considerar os professores como produtores de saberes, levando a uma desvalorização da profissão. Revela-se assim um distanciamento entre produção e execução de saberes (Tardif, 2012).

Sarti (2012) afirma que a profissionalização se apresenta como principal caminho para que os professores sejam mais autônomos e responsáveis pelo andamento dos trabalhos na instituição escolar, o que também demanda elevar o nível da formação profissional. Tardif (2013) alega que a profissionalização do ensino induz a uma visão reflexiva do ato de ensinar. Deve-se pensar a prática, problematizá-la, objetivá-la, criticá-la, melhorá-la, e não apenas executá-la. Para tal, é necessário que o professor esteja sempre em formação, de maneira que a formação docente necessita estabelecer novos modelos relacionais e participativos, diferentes do modelo tradicional conservador aplicacionista-transmissivo (Imbernón, 2009). Uma formação permanente, ao longo da vida, como um elemento constituinte da profissão docente, sendo entendida como um processo de desenvolvimento para a vida toda (Mizukami, 2002), onde se destacam a experiência pessoal e a prática profissional como importantes fontes de aprendizagem dos professores (Herneck e Mizukami, 2002).

Nóvoa (2019b) afirma que a formação continuada se constitui como um dos espaços mais importantes para uma reflexão conjunta, visando uma nova construção pedagógica na escola. A reflexão conjunta pode ser entendida como uma experiência social, como "reconhecimento e como crítica das relações de dominação entregue a marcos conceituais que, articulados à noção de profissional reflexivo, revelam tensões e problemas que os professores enfrentam na experiência de seu trabalho" (Tardif e Moscoso, 2018, p. 22). Os 
autores defendem que é indispensável considerar os conceitos utilizados na análise do trabalho docente e na formação dos professores.

No Brasil, a formação continuada é algo que foi conquistado pelos professores, com o Horário de Trabalho Pedagógico Coletivo (HTC), e foi garantida por meio da Lei do Piso que será abordada a seguir.

\subsection{A Lei do Piso (Lei Federal № 11.738/08) e o HTPC}

A política de valorização dos profissionais da educação como suporte para uma educação de qualidade deu respaldo às diretrizes políticas e legais definidas pela Lei Federal no 11.738/08, que regulamentou o piso salarial nacional para os profissionais do Magistério Público da Educação Básica. Esta lei também é conhecida como a Lei do Piso, na qual fixa o piso salarial nacional dos professores, afirmando que este piso é pago por determinada jornada, e explicitando como se compõe esta mesma jornada.

O piso salarial profissional nacional é o valor de vencimento inicial das Carreiras do magistério público da educação básica, para a jornada de, no máximo, 40 (quarenta) horas semanais, que deve ser garantido pela União, os Estados, o Distrito Federal e os Municípios (Brasil, 2008, p. 1)

No artigo segundo da Lei Federal n 11.738/08, no quarto parágrafo é citado: “Na composição da jornada de trabalho, observar-se-á o limite máximo de 2/3 (dois terços) da carga horária para o desempenho das atividades de interação com os educandos" (Brasil, 2008 , p. 1). Com isso, o docente tem à disposição $1 / 3$ (um terço) da carga horária para realização de atividades extraclasse, em que deve se especializar com estudos e capacitações, avaliar a aprendizagem do aluno e planejar ações pedagógicas para atividades a serem realizadas em classe.

Este tempo fora de sala de aula deve ser dividido em atividades de estudo, que se refere a um investimento na formação contínua, visando à qualidade da educação; o planejamento que está relacionado ao planejamento das aulas; e a avaliação, que se refere as atividades de acompanhamento do processo de ensino e aprendizagem dos alunos. (BrasiL, 2013).

Souza (2013) defende ser a primeira vez que os profissionais do magistério têm garantida em lei, com detalhamento, a sua jornada de trabalho. A Lei do Piso vem assegurar aos professores, além de um direito essencial referente ao mínimo de seus vencimentos, 0 direito à formação continuada. Porém, a Lei não garantiu sua adesão imediata pelos Estados brasileiros, e não tem garantido sua implementação mesmo após anos da sua aprovação, 
(Brasil, 2013), pois isso não é assegurado a todos aos professores. Clementino e Vieira (2020), afirmam que no ano de 2018, mesmo com a Lei do piso vigente, cinco estados brasileiros descumpriram a lei e não pagaram o piso salarial.

Freitas (2003) afirma que na maioria dos Estados e Municípios, os professores não recebem o Piso Salarial Nacional e estão sem formação continuada qualificada, e ainda são submetidos a condições de trabalho degradantes. De acordo com a autora, 82,2\% dos docentes da educação básica no Brasil possuem condições de formação, condições de trabalho, de valorização e remuneração de professores precárias, no sentido de que não têm sido tratados com a seriedade necessária, o que compromete o presente e o futuro do nosso país.

Teixeira (2016) ao realizar uma pesquisa sobre os impactos da lei do piso, em um município Baiano, afirma que, para os professores a Lei não promoveu a esperada valorização docente, pois os salário seguem aviltados, com inconsistências no plano de carreira, excessiva carga de trabalho, precárias de trabalho de trabalho, o que ainda demanda mobilização na direção de garantir tais direitos.

Alves e Pimentel (2015) ao analisarem a Lei do piso, identificaram que o Brasil enfrenta dificuldades com relação à implantação de políticas publicas para melhorar a remuneração dos profissionais do magistério público. Tal situação tem acarretado diversas implicações sobre a situação profissional dos professores, de modo que a política de valorização profissional por meio do piso salarial tem sido desenvolvida em meio a recursos insuficientes que culminam no descumprimento da lei pelos gestores estaduais e municipais.

Por um lado a proposição da lei do piso indica um avanço, pois o salário, a formação e a carga horária de trabalho são elementos importantes para a valorização da docência, mas por outro lado a sua efetivação ainda precisa ganhar maior atenção para que seja implementada de modo equitativo no território nacional (Freitas, 2003).

No âmbito da lei a disponibilidade de tempo de estudo/formação e planejamento dentro da carga horária de trabalho do professor são de 33\% da jornada. Nesse sentido, uma maneira de fazer cumprir a Lei do Piso é a formação acontecer na escola, permeando a idéia de não separação da formação ao contexto de trabalho.

De acordo com Mendes (2008), a formação centrada na escola pretende desenvolver um paradigma colaborativo entre os professores, de modo a responder às necessidades definidas pela escola para elevar a qualidade do ensino e da aprendizagem. Mas não é simplesmente mudar a formação de local, mas sim em mudanças de ideologias, valores, 
atitudes e crenças. A formação do professor deve ser encarada como um processo permanente junto ao seu dia a dia, por que é no contexto da escola que o professor enfrenta os desafios da prática docente (Candau, 1997; Imbernón, 2006; Nóvoa, 1995).

Devemos considerar que a defesa do HTPC aos professores, e a sistematização do mesmo através de Leis e Decretos não garante sua qualidade, nem de que os processos formativos tão referenciados e defendidos ocorram neste espaço/tempo. O que se pergunta é: sendo estes espaços extraclasses garantidos ao professor, o que é realmente realizado em relação à formação continuada? Como garantir ao professor modelos de formação com propostas que focalizem os professores como protagonistas na sua formação e na formação de seus pares? Os professores, por meio da formação continuada, conseguem produzir conhecimentos no intuito de impactar sua prática e fortalecer sua profissionalidade?

\subsection{A formação continuada}

Diante deste quadro, a formação continuada evidencia-se, então, como necessidade na vida profissional e como possibilidade de mudanças, com a reflexão e a reconstrução da prática (Sarti, 2012), pois se aprender a ensinar é um processo, então a formação do professor não se limita à formação inicial, podendo ser vista como um continuum (Mizukami, 2002; Tardif, 2012). Trata-se, no verdadeiro sentido do termo, de uma "formação contínua e continuada que abrange toda a carreira docente" (Tardif, 2012, p. 287).

Nóvoa et al. (2011) relatam que a maioria dos programas de formação é de pouca utilidade para os professores, pois muitas vezes se apresentam como cursos generalistas voltados para o professor enquanto indivíduo, no intuito de atualização do profissional, de maneira que não têm contemplado práticas baseadas no trabalho docente coletivo, ou condizentes com a realidade escolar de cada professor.

Com relação à Educação Física, a grande maioria de estudos realizados sobre a temática da formação continuada na área destaca a maior oferta por parte do poder público de modalidades de formação eventuais e de curta duração, muitas delas baseadas prioritariamente na transmissão de conhecimentos (Molina Neto, 1997; Gunther e Molina Neto, 2000; Rossi, 2010; Loureiro e Caparroz, 2011; Marin et al, 2011; Moreira et al., 2014; Ferreira, Henrique dos Santos e Costa, et al., 2015), que acabam por não contribuir efetivamente para o desenvolvimento profissional do professor, sendo cogente pensar em outras ações de formação, no qual este tem participação efetiva na construção de políticas de formação continuada, haja valorização da escola como um local de formação, e o ponto inicial desta 
formação continuada sejam as suas próprias práticas (Gunther e Molina Neto, 2000; Correia e Ferraz, 2010; Rossi, 2010; 2013; Loureiro e Caparroz, 2011).

Rossi (2010), em sua dissertação sobre formação continuada no campo da Educação Física, concluiu que muitos professores buscam o aprimoramento profissional freqüentando cursos e/ou outras atividades custeados com recursos próprios. Além disso, os docentes alegaram não haver espaço para se envolverem com as fases de elaboração e implementação das ações formativas, percebendo-se uma desvalorização dos saberes docentes. Os professores da pesquisa consideraram que a escola é o lugar privilegiado para a formação docente. A autora concluiu que a formação continuada tende a colocar o professor como principal agente da sua formação e da construção da sua profissionalidade docente, mas esta tendência para os professores de Educação Física ainda se apresenta distante.

Ferreira et al. (2015) em estudo sobre perfil de formação continuada de professores de Educação Física, verificaram freqüência maior de modalidades de formação consideradas tradicionais e de curta duração, com baixo nível de aprofundamento, em sua maioria proporcionada pelos sistemas de ensino. Essas modalidades são "estruturadas sob o modelo escolar de formação, em que as ações formativas privilegiam as necessidades dos sistemas de ensino e são compulsórias para os professores" (Ferreira et al., 2015, p. 296). Os perfis de formação que Ferreira et al. (2015) perceberam na pesquisa, corroboram os estudos sobre a realidade da formação continuada em Educação Física, que é presidida pela lógica da racionalidade técnica, e desvinculada da realidade educacional, sendo baseada na transmissão de conhecimentos, desvalorizando as experiências vividas pelos professores. Este modelo de formação continuada distancia-se do docente ao não contemplar suas necessidades, ao não levar em conta os problemas inerentes ao contexto educativo.

Silva (2014), ao pesquisar sobre a prática e formação de professores de Educação Física, afirma que o diálogo e interação entre os professores emergiram como um processo de formação continuada, pois foi tido como referência na constituição da identidade profissional, e fonte de consulta para a prática. Segundo a autora, esse diálogo gera uma cultura profissional, podendo se constituir em uma cultura de colaboração, o que contribui para o desenvolvimento da autonomia profissional, na perspectiva da profissionalização docente.

Nóvoa (2019b) afirma que é preciso reforçar as dimensões coletivas do professorado, para isso, é necessário uma nova construção pedagógica com professores empenhados em um trabalho de equipe que contemple uma reflexão conjunta. $O$ autor ressalta que a formação 
continuada se configura como um dos espaços mais importantes para promover a realidade partilhada.

O consumo de cursos, seminários e ações que caracterizam o atual mercado de formação deve ser substituído pelo "investimento na construção de redes de trabalho coletivo que sejam suporte de práticas de formação baseadas na partilha e no diálogo profissional" (Nóvoa et al., 2011, p. 536). Este modo de se fazer formação continuada defendido pelo autor, tem potencial para gerar produção de saberes pelos professores, que se legitimam como grupo capaz de produzir conhecimento. Isto leva à valorização do profissional e à profissionalização.

O grande desafio que se coloca atualmente é que a formação continuada não pode tratar de temas separados do contexto social, político, cultural e educacional dos professores. $\mathrm{Na}$ década de 1990, já havia a idéia de que o conhecimento desenvolvido pelos professores na prática é importante, desconhecido e pouco considerado pelas instituições de formação. (Molina Neto, 1997). As situações que os professores trazem da vivência escolar são únicas, e muitas vezes as técnicas passadas em formações com caráter transmissivo de conhecimentos, não conseguem dar conta desta complexidade, pois a certeza, a incerteza, a singularidade e o conflito fazem parte da multiplicidade da docência.

A proposta de formação continuada pode fornecer aos professores os meios para se chegar a um pensamento autônomo, e conduz a dinâmicas de formação participativa, possibilitando a troca de experiências, o compartilhamento de saberes e a produção destes saberes, transformando o professor no produtor de sua formação (Nóvoa et al., 2011). Nessa direção, a formação continuada deve ter lugar na escola com a participação das comunidades profissionais docentes. (Nóvoa, 2019b).

Assim, a formação continuada pode ser mais significativa quando possibilita a reflexão sobre a prática, sendo esta reflexão articulada aos conhecimentos que o professor possui, podendo ampliá-los (Nóvoa, 1995; Tardif, 2012).

A reflexão é um elemento importante no trabalho docente, pois ela se encontra no centro das práticas dos professores. Tardif e Moscoso (2018), ao desenvolverem uma análise ampliada sobre a reflexão no âmbito da docência, indicam que os professores como atores sociais devem fazer de suas práticas profissionais uma matéria de reflexão para lhes dar sentido.

A valorização, que os professores atribuem aos saberes da experiência, pode indicar a força da reflexão, pois "todos os professores destacam que o sentido de seu trabalho se encontra na experiência que têm dele. Essa experiência não emana de uma reflexão teórica, 
ela faz parte da reflexividade como princípio de compreensão do social" (Tardif e Moscoso, 2018, p. 17).

Nesse sentido, é necessário ao professor ter disponível tempo de estudo/formação dentro de sua carga horária de trabalho, prevista na lei do piso, para realizar a tarefa de reflexão sobre o seu trabalho. Neste tempo, ele poderá organizar e repensar sua prática, compartilhar experiências entre os pares, aprofundar seus conhecimentos, de modo a adquirir subsídios para desenvolver-se pessoal e profissionalmente, além de desenvolver o trabalho escolar (Nóvoa, 1995).

$\mathrm{Na}$ intenção de trazer à tona essa discussão, foi desenvolvido esse estudo, que tem por objetivo investigar como é estruturado, organizado e realizado o espaço-tempo dos HTPC da área da Educação Física da rede municipal, além de pesquisar os processos formativos presentes neste HTPC, buscando identificar em que medida estes professores têm se apropriado desses processos para o exercício docente.

\section{Metodologia}

\subsection{Enfoque}

Este estudo se apóia nos pressupostos da pesquisa qualitativa, na qual os dados coletados são descritivos, e o significado que as pessoas dão às coisas e à vida é foco da atenção do pesquisador. Esta pesquisa apresenta características de estudo de caso, pois é enfatizada a interpretação de um contexto que possui particularidades a serem investigadas de modo aprofundado. Assim, o foco está na formação continuada de professores de Educação Física, desenvolvida por meio de reuniões de Horário de Trabalho Pedagógico Coletivo (HTPC) de uma cidade do interior do estado de São Paulo, Brasil, em que há retratação da realidade de maneira completa e profunda (Lüdke e André, 1986).

O contexto da pesquisa se delimita ao HTPC específico da área da Educação Física, que ocorre em uma rede de ensino de um município do interior do estado de São Paulo, Brasil. O HTPC se caracteriza como uma unidade dentro de um sistema mais amplo, permitindo compreender algo singular, único e particular (Yin, 2015). Segundo o autor, a metodologia de estudo de caso contribui com o conhecimento dos fenômenos de certo grupo, e se centra em fenômenos contemporâneos inseridos em contextos da vida real. A seguir apresentamos o contexto da pesquisa desenvolvida. 


\subsection{Unidades de análise}

O caso de estudo a ser aqui investigado tem como particularidade o HTPC que é composto exclusivamente por professores de Educação Física atuantes em escolas de um município do interior paulista. A singularidade consiste no fato de que os professores participam das reuniões do HTPC nas escolas em que atuam, mas também possuem um HTPC específico da área da Educação Física, o que por si só pode nos oferecer pistas sobre o seu potencial formativo, pois isso não ocorre em outras áreas do conhecimento.

Assim, esta pesquisa está concentrada em investigar o desenvolvimento das atividades formativas com os professores participantes do HTPC específico da área da Educação Física.

Neste HTPC com um total de 40 professores de Educação Física, as reuniões eram semanais, com três horas e meia de duração, ao longo do ano letivo, sob a coordenação de uma professora também de Educação Física da rede, designada pela Secretaria Municipal de Educação (SME). Essas reuniões ocorriam no município desde 2009, e a participação dos professores é obrigatória, compondo a sua jornada de trabalho de 40 horas semanais, sendo 26 horas ministrando aulas com alunos, e as 16 horas restantes destinadas ao trabalho extraclasse, assim estruturadas:

- Horário de trabalho pedagógico individual (HTPI): duas horas;

- Horário de estudo na escola (HE): duas horas e trinta minutos;

- Horário de estudo em local de livre escolha $(\mathrm{HL})$ : três horas;

- Horário de trabalho pedagógico coletivo junto ao corpo docente da escola de maior carga horária de trabalho (HTPC): três horas;

- Horário de trabalho pedagógico coletivo realizado em conjunto com todos os professores de Educação Física (HTPC de área): três horas e trinta minutos.

A partir da perspectiva de compreender o caso do HTPC específico da área de Educação Física, todos os professores foram convidados a participar da pesquisa, de modo que poderiam declinar a sua participação a qualquer tempo, conforme os procedimentos éticos de pesquisa.

A pesquisa aqui apresentada teve aprovação do comitê de ética ${ }^{3}$, e o contato inicial se deu com a coordenação do HTPC, que após conhecer o objetivo da pesquisa, autorizou o convite aos professores de Educação Física da rede do município pesquisado.

\footnotetext{
${ }^{3}$ Parecer emitido sob o CAAE número 54595116.5.0000.5504.
} 
Com relação aos professores participantes do HTPC, houve a explanação sobre a pesquisa em questão, e após, foram convidados a participar da pesquisa. Todos os professores que manifestaram o desejo de participar assinaram o termo de consentimento, e as identidades foram mantidas em sigilo, assim como informamos que eles poderiam, a qualquer tempo, declinar de sua participação sem que houvesse qualquer tipo de prejuízo.

A partir do consentimento dos participantes, obtivemos a participação da professora coordenadora do HTPC, e houve o acompanhamento das reuniões ocorridas durante um ano letivo.

\subsection{Técnicas de coleta de dados}

Para a obtenção dos dados, foram utilizados os seguintes instrumentos de coleta de dados: a análise documental, questionário e entrevista semiestruturada.

O questionário, com questões fechadas e abertas, subdividiu-se em quatro temas, a saber: I - Identificação; II - Estrutura e organização do HTPC; III - Ações de formação; e IV Processos formativos no HTPC e prática pedagógica. A rede municipal contava com 46 professores de Educação Física no ano em que foi feita a pesquisa.

Assim, no mês de março do mesmo ano foram distribuídos o questionário e o Termo de Consentimento Livre e Esclarecido a 40 professores, e foi explicado que teriam uma flexibilidade de tempo para a devolução do questionário respondido. No momento da entrega dos questionários, foi realizada explicação oral da pesquisa aos professores e a leitura do Termo de Consentimento. Até o final do mês de junho, 30 professores entregaram o Termo de Consentimento Livre e Esclarecido e o questionário respondido, totalizando $75 \%$ de devolutiva. As respostas foram categorizadas para posterior análise.

A entrevista ocorreu com a coordenadora do HTPC da Educação Física, no intuito de aprofundar os dados coletados nas atas, e nos questionários. De acordo com Lakatos e Marconi (2003, p.195) "A entrevista é um encontro entre duas pessoas, a fim de que uma delas obtenha informações a respeito de determinado assunto, mediante uma conversação de natureza profissional". Optou-se pela entrevista semiestruturada, pois esta fornece ao pesquisador um planejamento estendido acerca do conteúdo abordado, possibilitando a abertura para formulação de novas questões no decorrer da entrevista.

Assim, dos 30 professores que devolveram o questionário respondido, 20 eram mulheres e 8 homens, e 2 não responderam a questão. As idades variam entre 20 a 50 anos. A grande maioria dos professores (24) se formou em instituição privada de ensino superior, 
sendo que 4 professores se formaram em instituição publica e outros 2 não forneceram essa informação.

Com relação ao tempo de docência dos professores participantes da pesquisa, foram 7 professores com tempo de atuação profissional entre 1 a 3 anos, portanto na fase inicial da carreira; 10 professores entre 4 a 6 anos de tempo de atuação, o que indica a fase de estabilização; e 12 professores entre 7 e 25 anos, etapa da diversificação.

Huberman (1995), ao discorrer sobre o tempo de docência dos professores, propõe ciclos, ou estágios da profissão, sendo o primeiro o estágio de Início ou de Exploração, correspondente aos três primeiros anos da profissão, onde acontece a confrontação inicial com a complexidade da situação profissional, além da descoberta, que se traduz por fazer parte de um corpo profissional, de assumir responsabilidades docentes. O segundo estágio, que se inicia a partir do quarto ano de docência, e dura de quatro a seis anos, seria o de Estabilização, no qual o docente escolhe ser professor, e apresenta maior domínio e confiança no seu trabalho, repercutindo em liberdade e segurança. O terceiro ciclo, de Diversificação, acontece por volta dos dez até os 25 anos de trabalho docente, e traz uma busca por novos desafios, numa necessidade de manter um entusiasmo pela profissão. Essa fase pode perdurar por muitos anos, e pode gerar em alguns uma progressiva sensação de rotina, sem a ocorrência de uma atividade inovadora significativa.

Para se proceder à análise histórica da estruturação do HTPC da área da Educação Física, e à análise documental, realizou-se a leitura e análise de 36 atas de reuniões ocorridas no ano. As atas são registros sobre as atividades desenvolvidas nas reuniões de HTPC, e por meio delas pudemos identificar os procedimentos das reuniões, bem como as temáticas abordadas ao longo do ano letivo.

Em um segundo momento da pesquisa, com o intuito de aprofundar os dados coletados nas atas, e nos questionários coletados, foi realizada a entrevista semiestruturada com a coordenadora do HTPC. A entrevista realizada com a coordenadora, foi necessária para obtermos maior compreensão sobre as reuniões formativas, visando complementar informações coletadas nas atas analisadas. Para a realização da entrevista foi agendado um horário com a coordenadora, de modo que a entrevista foi individual e gravada em áudio e, posteriormente, transcrita integralmente para análise do seu conteúdo.

Com relação à coordenadora do HTPC, esta iniciou como docente de Educação Física na Rede no ano de 2009. Apresenta oito anos de docência, atuando há sete como professora de Educação Física na rede municipal. Possui formação em Licenciatura Plena em uma 
universidade privada, com Mestrado em Educação Física pela mesma instituição. Tem a idade de 31 anos.

Em artigo que versa sobre o professor como formador de seus pares, Budin e Sarti (2017) afirmam que uma das características importantes para seleção dos professores formadores refere-se ao nível de formação acadêmica, os quais apresentavam uma significativa inserção acadêmica, o que vai ao encontro ao dado referente à coordenadora do HTPC da área da Educação Física, que além de Mestrado em Educação Física, participa de grupo de estudo na área de Educação Física escolar, em uma Universidade pública Paulista.

\subsection{Análise dos dados}

Para a análise dos dados coletados, Lüdke e André (1986) relatam que o pesquisador deve trabalhar o material coletado, buscando destacar os principais achados da pesquisa, na tentativa de buscar elementos substanciais à elucidação das principais questões investigadas. As autoras ressaltam que os dados devem ser tratados com cuidado e atenção.

Com relação à análise das atas foram realizadas leituras relativas ao seu conteúdo, e agrupadas de acordo com os assuntos abordados, na intenção de formular categorias de análises. Os questionários e a entrevista com a coordenadora foram analisados, com o intuito de organização do material, sistematizado a partir do teor das questões e em função da idéia transmitida pelos participantes em cada uma das respostas.

As categorias de análises foram determinadas a partir das recorrências das respostas identificadas nos dados coletados. De acordo com Lüdke e André (1986, p. 48), "é preciso que a análise não se restrinja ao que está explícito no material, mas procure ir mais a fundo, desvelando mensagens implícitas, dimensões contraditórias e temas sistematicamente 'silenciados"'.

A partir da análise dos dados, foram organizados três tópicos a saber: 1) Estrutura e organização do HTPC; 2) Processos formativos presentes no HTPC; 3) Os processos formativos no HTPC e a prática pedagógica.

\section{Resultados}

\subsection{Estrutura e organização do HTPC}

O HTPC se estrutura basicamente em quatro momentos. O primeiro trata dos informes, no qual são repassados avisos e considerações referentes à Secretaria Municipal de Educação (SME), e são esclarecidas questões burocráticas. No segundo momento, são 
apresentadas Aulas Temáticas ${ }^{4}$, textos, artigos, ou quaisquer outras atividades que se relacionam com a formação dos professores. É o momento no qual se disponibiliza mais tempo do HTPC, e os professores dão opiniões, e se posicionam sobre os assuntos tratados. $O$ terceiro momento se destina ao planejamento semanal das aulas a serem ministradas pelos professores. O quarto momento é o fechamento, no qual acontece a roda final com a finalização dos trabalhos do dia, e organização do que ficou pendente, e o que será complementado nas próximas reuniões.

Com relação à definição das pautas das reuniões, os professores colocam que são definidas pela coordenadora, e são consideradas as demandas e necessidades do grupo. A coordenadora enfatiza que "a todo tempo, o que nós íamos fazer era aberto também para os professores sugerirem, trazerem, pra que esse HTPC realmente atingisse e desses subsídios para o professor em sala de aula" (COORD 01). A coletividade na estruturação das ações se faz presente neste espaço/tempo.

Nos questionários, foi identificado que o HTPC para os docentes que fazem parte da pesquisa é um momento de formação continuada (28\%), possibilitando a partilha de suas experiências, a reflexão sobre suas práticas, e o debate acerca de propostas pedagógicas, além da vivência de momentos formativos coletivos junto a seus pares (68\%).

Nóvoa (1995, p. 14) diz que "a troca de experiências e a partilha de saberes consolidam espaços de formação mútua, nos quais cada professor é chamado a desempenhar, simultaneamente, o papel de formador e de formando". Segundo o autor, é a reflexão coletiva que dá sentido ao desenvolvimento profissional. Tardif, Lessard e Gauthier (2001) consideram que os professores produzem saberes específicos ao seu próprio trabalho e são capazes de deliberar sobre suas próprias práticas, de objetivá-las e partilhá-las, de aperfeiçoá-las e de introduzir inovações susceptíveis de aumentar sua eficácia.

Entretanto, há também alguns aspectos menos significativos do HTPC da área da Educação Física, como os relatos sobre a destinação de muito tempo às questões burocráticas, o que torna o HTPC distante das discussões sobre a área da Educação Física. Nessa direção, há a idéia de que "o HTPC deveria tentar esclarecer as dúvidas dos professores. Nem sempre acontece” (PROF 02). Há um incomodo dos professores com relação aos assuntos tratados durante o HTPC, pois são "questões administrativas sendo

\footnotetext{
${ }^{4}$ A formação continuada no HTPC ocorre também quando os próprios professores oferecem uma formação sobre um tema específico, apresentando projetos desenvolvidos, práticas adotadas, ou assuntos de maior conhecimento. São chamadas Aulas Temáticas, especificadas nos questionários, nas atas das reuniões, e na entrevista com o coordenador. Nelas, os pares demonstram atividades que deram certo nas suas aulas, compartilhando-as.
} 
tratadas em momento pedagógico" (PROF 10), as que na visão de alguns professores não estão condizentes com a proposta do HTPC.

Percebemos haver a participação ativa dos professores neste espaço/tempo, sendo eles responsáveis, juntamente com a coordenadora, pela formação continuada. A constante interação permite o compartilhamento de experiências que promove o crescimento profissional dos professores, pois a aprendizagem como processo formativo demanda reflexão coletiva a partir da análise de situações concretas do trabalho do professor. Além disso, há também a busca colaborativa de mais informações para originar novo conhecimento profissional e desenvolvimento de ações de ensino de modo que esse processo seja partilhado (Veiga Simão et al., 2009).

\subsection{Os processos formativos presentes no HTPC de área}

Tanto a coordenadora quanto os professores que responderam ao questionário, afirmaram existir momentos de formação continuada dentro do HTPC da Educação Física. Através da análise das atas, identificamos os diferentes momentos formativos bem como as atividades explicitadas nesses momentos. Assim, os processos formativos foram: a) realizados por professores externos convidados pela coordenação do HTPC; b) Formação por meio do estudo do meio; c) Formação por meio de aulas temáticas; d) Formação direcionada pela coordenação do HTPC. A seguir apresentamos os momentos e atividades identificados como formativos pelos participantes da pesquisa, sumarizados na ¡Error! No se encuentra el origen de la referencia..

Tabela 1: Atividades Formativas realizadas nas diferentes Formações Continuadas

\begin{tabular}{|c|c|c|c|}
\hline $\begin{array}{lr}\text { Formação } & \text { Pontual } \\
\text { realizada } & \text { por } \\
\text { professores convidados }\end{array}$ & $\begin{array}{l}\text { Formação através de } \\
\text { estudo do meio }\end{array}$ & $\begin{array}{l}\text { Formação por Aulas } \\
\text { Temáticas }\end{array}$ & $\begin{array}{l}\text { Formação ofertada pela } \\
\text { coordenadora do HTPC } \\
\text { da Educação Física }\end{array}$ \\
\hline $\begin{array}{l}\text { Atividades rítmicas e } \\
\text { expressivas; } \\
\text { Pedagogia do Esporte nos } \\
\text { anos iniciais do Ensino } \\
\text { Fundamental; } \\
\text { Inclusão na escola. }\end{array}$ & $\begin{array}{l}\text { Visita ao museu do } \\
\text { Futebol -São Paulo; } \\
\text { Visita ao Museu Afro } \\
\text { Brasileiro; } \\
\text { Jornada Pedagógica } \\
\text { do município. }\end{array}$ & $\begin{array}{l}\text { Recursos Audiovisuais } \\
\text { Cordas duplas } \\
\text { Karatê } \\
\text { Registros das avaliações } \\
\text { diárias } \\
\text { Avaliação } \\
\text { Protagonismo juvenil e } \\
\text { cooperativismo } \\
\text { Contação de história } \\
\text { Xadrez } \\
\text { Queimada dos sexos } \\
\text { Brincadeira MyGod } \\
\text { (Moçambique) }\end{array}$ & $\begin{array}{l}\text { Jogos de Tabuleiro e Mesa } \\
\text { com o Corpo; } \\
\text { Brincadeiras e jogos } \\
\text { africanos trabalhados no } \\
\text { mês da Consciência Negra }\end{array}$ \\
\hline
\end{tabular}


Jogos e brincadeiras

Fonte: as autoras

As atividades formativas ocorridas no HTPC foram identificadas como experiências positivas para os professores, configurados em diferentes formatos. As afirmações vão à direção de que "muita coisa nestes anos de Rede municipal, aprendi nos HTPC. As trocas entre os colegas de área sempre foram muito boas" (PROF 19), e que "o professor conhece novas atividades e pode colocá-las em prática, discutindo sobre sua realidade com outros da mesma área" (PROF 15). Nóvoa (2019b) afirma que a "metamorfose da escola" acontece quando os professores se unem em coletivo para pensar o trabalho, e para construir práticas pedagógicas que respondam aos desafios colocados.

Tardif (2012) defende que os saberes experienciais são aqueles desenvolvidos no cotidiano da escola, de modo que os momentos formativos envolvem o compartilhamento e o estabelecimento de relações de aprendizagem desses saberes entre os docentes. Essa idéia foi encontrada nos dados da pesquisa aqui apresentada.

As trocas de experiências no HTPC foram recorrentes nas falas dos participantes. É a partir das relações com os pares, do confronto entre os saberes da prática produzidos por todos os professores de Educação Física, que os saberes experienciais adquirem certa objetividade, sendo capazes de fornecer respostas às dificuldades que apresentam em relação à prática. Tardif (2012, p. 87) afirma que uma "fonte de aprendizagem do trabalho docente é a experiência dos outros, dos pares, dos colegas que dão conselhos".

A existência de momentos de interação e troca de saberes com os colegas foi relatada do seguinte modo: "Durante todo HTPC os professores expõem suas idéias e acabam se relacionando" (PROF 02). "Estas interações ocorrem durante o tempo destinado ao planejamento, nas apresentações e discussões das aulas temáticas, nas dinâmicas propostas, enfim, todo espaço de formação tem seu momento de trocas” (PROF 07). "A interação é muita durante todo o encontro no HTPC. Formam-se grupos para discussão de temas. O objetivo é 
a troca (rica) de experiências, pois somos professores com formações diferentes e vindos de experiências diferentes” (PROF 17). "O pensar coletivamente é recorrente e se traduz principalmente na manifestação e exposição de idéias. Fato evidenciado nas discussões sobre determinado tema, organização de eventos, planejamento de aula, etc.” (PROF 01).

Nos depoimentos dos professores há uma ênfase nas interações entre os pares, no sentido de que há a possibilidade de conhecer as diferentes maneiras de pensar, advindas também das diversas experiências compartilhadas no grupo.

As experiências dos professores propiciam reflexões sobre o próprio trabalho, Tardif e Moscoso (2018) afirmam que "os professores devem fazer de suas práticas profissionais uma matéria de reflexão, para lhes dar sentido".

Marcolino, Lourenço e Reali (2020, p. 412) ressaltam que a reflexão pode ser considerada como um processo "de fazer-significar, que conduz o sujeito de uma experiência para outra, propiciando maior compreensão das relações que se estabelecem com outras experiências e idéias, favorecendo tanto a redefinição dos significados das ações como a produção de novos conhecimentos".

Veiga Simão, Flores, Morgado, Forte e Almeida (2009, p. 64) afirmam que o sucesso da formação continuada "depende da capacidade das escolas se envolverem na concepção e desenvolvimento colectivo de projectos de formação que respondam às suas necessidades e que permitam encontrar respostas para os problemas com que se deparam no seu dia-a-dia".

O HTPC aqui estudado, leva em consideração que o planejamento é um momento privilegiado, em que pode haver a participação dos professores de modo coletivo, como podemos notar a seguir:

[...] as trocas aconteciam muito no momento do planejamento. Então tinha lá quarenta minutos uma hora do planejamento e a gente percebia. (COORD 01).

Existe um tempo reservado para planejamento onde os professores utilizam para se reunir com os demais professores e compartilhar experiências. O objetivo é tentar ajudar o colega no seu planejamento e colaborar de maneira positiva para a solução de problemas (PROF 09).

De acordo com Veiga Simão et al. (2009, p. 64), “a formação contínua deve fomentar o desenvolvimento de práticas colaborativas nas escolas", pois o trabalho em equipe, pode alavancar o desenvolvimento de uma "atitude docente mais autônoma e de construção de uma "nova" cultura docente". Nóvoa (2019b, p. 6) afirma que "Não é possível aprender a profissão docente sem a presença, o apoio e a colaboração dos outros professores". 
Quando os professores afirmam que os conhecimentos dos colegas são importantes e geram aprendizados, eles se tornam protagonistas na formação de seus pares: "acredito que quando um colega de profissão ministra uma aula para o grupo estamos participando de uma formação" (PROF 02); "[...] ao estar em contato com os outros professores, um apresenta sugestões para os demais, influenciando e refletindo em nossa prática” (PROF 15).

Segundo Imbernón (2011, p. 86) a formação centrada na escola tem como propósito a colaboração entre os professores, na qual o professor é sujeito e não objeto de formação. Parte-se do pressuposto de que "o profissional de educação também possui uma epistemologia prática, possui um quadro teórico construído a partir de sua prática".

Davis, Nunes, Almeida, Silva e Souza (2012) colocam que ao refletir e discutir entre os seus pares, espera-se que os professores sejam capazes de estabelecer um clima de confiança, que permita o entrosamento com diferentes níveis de experiência, o que é propício ao aprendizado coletivo. Para Nóvoa (1995), a concepção de espaços coletivos de trabalho pode constituir um excelente instrumento de formação. Este clima de confiança é construído coletivamente, e depende também do coordenador:

[...] eu enquanto coordenadora, no meio das discussões, das trocas eu sempre falava: o que você acha disso tentava ouvir, tentava fazer esse professor pelo menos na hora do coletivo se colocar pra gente conhecer um pouco do trabalho dele também. E ele de repente reconhecer que o trabalho dele também é bom, que ele pode falar que ele é ouvido (COORD 01).

Nóvoa (2019b, p. 6) indica a necessidade de um novo ambiente para a formação profissional docente, no sentido de reconstruir o ambiente, uma vez que "o lugar da formação é o lugar da profissão".

O modo como o ambiente profissional de trabalho é organizado, afeta a maneira de como o trabalho com os professores é desenvolvido, assim o papel da coordenação aqui assume grande importância ao desenvolver as ações formativas junto aos professores. $\mathrm{O}$ apoio de pessoas que têm o papel de liderança, junto aos professores, contribui para auxiliar a implementar mudanças apropriadas no seu contexto de trabalho (Hargreaves, 2002).

\subsection{Os processos formativos e a prática pedagógica}

O HTPC proporciona aos professores aprendizados para a prática, como percebido nos relatos: "[...] através das aprendizagens (no HTPC), posso modificar tudo que for necessário para adaptar minha realidade na escola, proporcionando a melhor aula possível" (PROF 05); "[...] me baseio muito nos aprendizados durante o HTPC para prática docente" (PROF 25). 
Veiga Simão et al. (2009, p. 65) ao tratar sobre contextos colaborativos, defende que o contexto de trabalho como um local de construção de conhecimento profissional de professores que possibilita um ir e vir entre teoria e prática, no sentido de que há um movimento de interpretação, desafio e interrogação sobre os diferentes contextos de prática profissional. Segundo os autores, "a emergência deste conceito de formação em contexto implica, para a formação de professores, que estes se mobilizem com o objectivo de, em trabalho colaborativo, enfrentar as tensões inerentes à função educativa e, em conjunto, tentarem ultrapassá-las"

De acordo com os resultados obtidos, $80 \%$ dos professores lançam mão de saberes experienciais para ministrar aulas. Pesquisas realizadas por Tardif (2012) apontam que, para os professores, saberes adquiridos através da experiência profissional constituem os fundamentos de sua competência, fato que foi constatado nesta pesquisa: "a partir do repertório oferecido e troca de informações semanalmente, conseguimos montar nossas aulas com qualidade" (PROF 04); "[...] muito do que é discutido eu utilizo nas minhas aulas" (PROF 11); "as atividades desenvolvidas e as experiências trocadas com outros profissionais auxiliam e muito minha prática. Abre meu leque de atividades para ministrar" (PROF 26); "[...] tudo que é discutido e apresentado torna-se em aulas práticas/teóricas, auxiliando no planejamento" (PROF 30).

Hargreaves (2002) afirma que quando os professores experimentam o trabalho colaborativo, eles valorizam as oportunidades e o encorajamento proporcionados para implementar inúmeras iniciativas. De modo que as culturas de trabalho colaborativo motivam os professores, para entenderem juntos sobre as iniciativas que deveriam pôr em prática.

O trabalho colaborativo, impresso no HTPC, possui muitos elementos que auxiliam os professores, mas é preciso que haja também um envolvimento "em um processo de reflexão sobre a ação - um processo intencional, atrelado ao fazer, após sua ocorrência, e que demanda uma ação conseqüente qualitativamente diferente de uma ação rotineira". Desse modo, a reflexão permite uma maior compreensão sobre as relações estabelecidas em outras experiências, o que permite uma "redefinição dos significados das ações como a produção de novos conhecimentos" (Marcolino et al., 2020, p. 412).

A prática compartilhada é entendida como auxílio em situações difíceis para os professores, de modo que para um dos professores "A prática era compartilhada com os colegas, gerando menos angustias docentes quando algo não ocorria como planejado (por exemplo, uma aula/planejamento que não funcionou)" (PROF 22). 
A prática profissional se desenvolve em um determinado tempo e contexto, e contém situações singulares e complexas, dentro disso, é importante que o professor reflita sobre a sua prática, mas também sobre as práticas dos colegas, abarcando assim dimensões reflexivas e interativas no trabalho docente.

Davis et al. (2012) enfatiza que por meio da colaboração entre pares, é capaz de proporcionar uma discussão rica acerca dos vários fatores da profissão docente, sendo capaz de aumentar a consciência a respeito de seus aspectos críticos, e incentivar também a experimentação didática, o uso de novas estratégias de ensino e a adoção de uma organização mais eficiente da prática docente.

Quando os professores analisam e escrevem sobre os eventos que ocorrem em sala de aula, eles estão criando seus próprios conhecimentos, seus saberes. É um ato em que o professor tenta perceber sua própria maneira de pensar e agir quando ministra suas aulas, podendo construir um saber a partir disto, o saber baseado na própria experiência bem como a dos colegas.

Nóvoa (2019b, p. 203) ao tratar da formação de professores, considera a necessidade de espaços coletivos para novas práticas pedagógicas. E, dentro disso, indica a criação de um novo lugar institucional, no qual haja uma integração entre a universidade e um conjunto de escolas de educação básica. "A intenção é constituir, coletivamente, espaços de experimentação pedagógica e de novas práticas que sejam ambientes propícios à formação dos jovens professores".

A coordenadora indica que as formações podem auxiliar à superar algumas dificuldades, pois:

[...] muitos professores gostavam do HTPC por ele ser por área, elogiavam e diziam no HTPC posterior, por exemplo: nossa, na semana passada o que a gente trabalhou foi muito legal, consegui fazer na escola, saí daqui com meu planejamento pronto, isso foi muito bom (COORD 01).

O depoimento da coordenadora pode nos indicar uma compreensão de que a formação continuada por meio do HTPC pode provocar influencias na prática dos professores de Educação Física. Essa idéia pode ser corroborada nas respostas a seguir.

"Quando entrei na Rede eu não tinha nenhuma noção de como era trabalhar numa escola. Através do HTPC pude receber ajuda em relação a alguns conteúdos que não tinha 0 pleno domínio" (PROF 09). "Muitas atividades colocadas no HTPC foram aplicadas em prática 
nas aulas, muitas situações problemas foram resolvidas, pois os colegas opinaram e deram sugestões para solucionar" (PROF 03).

A prática mobilizada pelos professores nas escolas se constitui como espaço fundamental para se produzir, e aprender os saberes da profissão. A prática não é somente um lugar de aplicação e transmissão de saberes provenientes da teoria, e sim, um espaço de produção de novos conhecimentos específicos oriundos da mesma prática (Tardif, 2012). 0 HTPC da área possibilita ao professor compartilhar esta prática: "[...] debatemos nossa prática docente e conseguimos ver várias possibilidades em nossas práticas, com diversas opiniões e visões diferentes" (PROF 21); "quando há diversidade de pensamentos e atitude, me faz pensar e procurar raciocinar mais" (PROF 08); "Os objetivos, as atividades desenvolvidas e a estruturação do HTPC possibilitam aprendizagens para a prática docente, pois valoriza e incentiva uma reflexão crítica da mesma. (PROF 01).

O compartilhamento de experiências é uma forma de aprender coletivamente. Nóvoa (2019a) indica que instaurar processos coletivos de trabalho, implica em mudanças relativas à organização das escolas e da própria profissão docente. Nessa perspectiva, o conhecimento experiencial é compreendido como um conjunto de representações pelas quais os professores compreendem e interpretam a profissão, bem como a própria prática, constituindo assim a cultura do ensino em ação. No âmbito desta cultura de ensino a prática profissional pode promover a busca pela reorganização dos saberes a partir das exigências do trabalho docente (Souza Neto, Vedovatto Iza e da Silva, 2017).

Os processos sobre as formas de ensinar do professor envolvem uma reflexividade crítica, que se constitui a partir de uma interpretação crítica sobre os fenômenos educacionais o que implica diálogos consigo, com os pares e pautados nas situações vividas.

Cochran-Smith (2012) propõe a "desprivatização" da prática, se refere a deixar de conceber o ensino como um ato privado, nesse sentido a mudança com relação a isso pode ser alavancada por meio de uma variedade de processos e perspectivas que podem se abrir, ou seja, para tornar o trabalho público e aberto à crítica. A autora sugere que a "desprivatização" seja o fim do isolamento, visando promover a construção do conhecimento, e o mútuo trabalho de colaboradores em comunidades. Gauthier et al (1998), em direção semelhante, propõem tornar públicas as experiências escolares alicerçadas na ciência. 


\section{Conclusões}

Esta pesquisa teve como objetivo analisar os processos formativos presentes no HTPC da área Educação Física, buscando identificar em que medida os professores se apropriam de tais processos para o exercício docente. As diferentes atividades realizadas possibilitaram, aos professores, vislumbrar novas possibilidades de trabalho, bem como ampliar seus conhecimentos, diminuindo assim, angústias e questionamentos que surgem no decorrer de suas práticas cotidianas de trabalho.

Com relação à estrutura e organização do HTPC, há uma divisão de tempos para as atividades formativas, além disso, também foi identificado que os professores tem papel fundamental na constituição do HTPC. E, ainda que haja também o relato crítico sobre os tempos destinados aos aspectos burocráticos do trabalho, é imprescindível destacar que a organização e estrutura do HTPC, na qual os professores são protagonistas, propicia consideráveis trocas de experiências entre os professores, de modo bastante significativo.

No espaço/tempo do HTPC, as experiências socializadas com todos os colegas da área de conhecimento específico representam oportunidades singulares para os professores de Educação Física, pois o trabalho conjunto pode promover o crescimento tanto individual como coletivo.

Com relação aos processos formativos presentes no HTPC foram identificados por meio das atividades propiciadas envolvendo a formação com professores convidados; a formação através do estudo do meio; por aulas temáticas; e por meio das atividades desenvolvidas pela coordenadora do HTPC.

A formação não se dá de maneira unilateral, o que favorece a elaboração, trocas, ressignificação e análise das práticas vividas pelos docentes, gerando a valorização do saber advindo das diferentes experiências. Os processos formativos identificados nas diversas ações do HTPC geraram diferentes saberes, assim por meio deste trabalho identificamos que muitos elementos desenvolvidos no HTPC de área estavam diretamente relacionados com o desenvolvimento das práticas dos professores nas escolas.

O planejamento das atividades, os desafios e dificuldades encontradas nas escolas, bem como o levantamento de alternativas de solucioná-las foram alguns dos aspectos que nos indicam a presença dos processos formativos no âmbito do HTPC junto às práticas pedagógicas dos professores de Educação Física. Além disso, a própria organização do HTPC prevê estreita relação com a prática dos professores, bem como um protagonismo para o 
desenvolvimento das reuniões do HTPC, o que gera um movimento de constante reflexão entre a prática desenvolvida nas escolas, e a formação continuada no HTPC.

Nessa direção, os processos formativos no HTPC e as práticas pedagógicas se destacam como um movimento em que a prática recebe influência da formação obtida no HTPC, uma vez que há, no compartilhamento das experiências, uma ampliação sobre as possibilidades de trabalho pedagógico.

Esse movimento parece nos dar indícios de uma possível "desprivatização" das práticas pedagógicas, que permitem que os professores compartilhem o seu trabalho com os pares, e por meio do diálogo produzam um espaço de formação continuada bem como de reflexões sistematizadas sobre o trabalho docente.

É importante ressaltar que, diante do exposto, o HTPC da área da Educação Física aqui estudado, pode ser caracterizado como uma ação que vai ao encontro de ações de valorização docente, no que se refere à formação contínua no âmbito do que se defende na Lei do piso.

É preciso considerar que, este trabalho esteve delimitado e circunscrito em um período de tempo, de um ano letivo, de desenvolvimento do HTPC de área investigado, por isso tem o limite do recorte temporal, certamente um estudo longitudinal, e a ampliação dos instrumentos de coleta de dados, poderiam estender o enfoque do estudo aqui apresentado, bem como a realização de investigações com outros grupos de profissionais ou equipes gestoras da mesma rede de ensino, o que pode ser desenvolvido em pesquisas futuras.

Mas é importante dar relevo para a iniciativa aqui apresentada na qual o professor é colocado como um protagonista de processos formativos diversos, ao mesmo tempo em que é parte de um coletivo maior que se propõe ser colaborativo.

A formação continuada ocupando um lugar na escola, e com a participação comprometida dos professores, pode efetivamente produzir uma formação com base nas experiências profissionais, sem deixar de considerar também os conhecimentos das universidades e grupos de pesquisa, que podem oferecer uma interface bastante profícua. Pensar o trabalho docente, de modo coletivo, para responder aos desafios contemporâneos, pode produzir práticas diferenciadas, e quiçá projetar outros modelos escolares. Este pode ser um desafio a ser enfrentado.

Assim, é primordial que haja a proposição de uma política de formação continuada para os professores de modo que eles possam se aprimorar no seu trabalho junto aos alunos, além disso, é preciso recuperar a dignidade do trabalho docente pela implementação da Lei do Piso em sua integralidade na qual ocorra o efetivo estabelecimento de $1 / 3$ das horas para 0 
desenvolvimento das atividades de preparação e avaliação do trabalho docente. (Lira, 2015; Freitas, 2003).

A existência do HTPC de área foi resultado de uma política do município que promoveu esse espaço e tempo para os professores, oferecendo as condições necessárias para que houvesse a participação de todos nas reuniões de HTPC. Mas é igualmente importante enfatizar que também houve o comprometimento dos profissionais envolvidos em serem protagonistas neste processo de formação continuada. A criação e manutenção do HTPC em questão permitiram significativo desenvolvimento profissional, o que contribuiu para o trabalho docente nas escolas, e para o processo de profissionalização do ensino.

A experiência aqui apresentada revela ações que podem inspirar outros contextos, na medida em que há uma formação que tem como idéia central o professor como protagonista e os processos de análise e reflexão sobre os temas propostos. Mas, é crucial enfatizar que tal experiência foi oportunizada por meio de ações ligadas ao que é previsto na lei do piso, e nessa direção, é fundamental que ocorram ações que visem a efetiva concretização de uma política de formação, profissionalização e valorização dos professores no país.

\section{Referências}

Alves, Charles Alberto de Souza., e Pimentel, Adriana Marinho. (2015). O Piso Salarial Profissional Nacional dos professores da educação básica pública: desafios atuais e perspectivas. Revista de Financiamento da Educação, 5(6). Recuperado de https://seer.ufrgs.br/fineduca/issue/view/2915

Brasil. (2008). Lei número 11.738, de 16 de julho de 2008, que institui o piso salarial profissional nacional para os profissionais do magistério público da Educação Básica. Brasília, Brasil: Casa Civil.

Brasil. (2013). Reexame do Parecer CNE/CEB $n^{\circ}$ 9/2012, que trata da implantação da Lei $n^{\circ}$ 11.738/2008, que institui o piso salarial profissional nacional para os profissionais do magistério público da Educação Básica. Brasília, Brasil: Ministério da Educação.

Budin, Clayton., e Sarti, Flavia. (2017). O professor de educação básica como formador de seus pares: possibilidades para a profissionalização docente. Perspectiva, 35(2),578597. doi: http://dx.doi.org/10.5007/2175-795X.2017v35n2p578

Candau, Vera Maria. (1997). Formação continuada de professores: tendências atuais. In V. M. F. Candau (Ed.), Magistério: construção cotidiana (pp. 51-68). Petrópolis, Brasil: Editora Vozes.

Cochran-Smith, Marilyn. (2012). Uma História de Dois Professores: Aprendendo a Ensinar com o Tempo. Kappa Delta Pi Record, 48(3), 108-122. doi: https://doi.org/10.1080/00228958.2012.707501 
Contreras, Javier. (2002). Autonomia de professores. São Paulo, Brasil: Cortez.

Correia, Rodrigo Nuno Peiró., e Ferraz, Osvaldo. (2010). Competências do professor de educação física e formação profissional. Motriz: Revista de Educação Física, 16(2), 281$291 . \quad$ Recuperado de http://www.periodicos.rc.biblioteca.unesp.br/index.php/motriz/article/view/2910/2918

Clementino, Ana Maria., e Vieira, Lívia Fraga. (2020). Carreira e Avaliação Docente na Educação Básica no Brasil: Emergência de Novo Profissionalismo. Sisyphus Journal of Education, 8(1), 55-78. doi: https://doi.org/10.25749/sis.18989

Davis, Claudia., Nunes, Marina., Almeida, Patricia., Silva, Ana Paula., e Souza, Juliana. (2012). Formação continuada de professores: uma análise das modalidades e das práticas em estados e municípios brasileiros. São Paulo, Brasil: FCC/DPE. Recuperado de http://publicacoes.fcc.org.br/index.php/textosfcc/article/download/2452/2407/9327

Ferreira, Janaina da Silva., Henrique dos Santos, Jose., e Costa, Bruno de Oliveira. (2015). Perfil de formação continuada de professores de Educação Física: modelos, modalidades e contributos para a prática pedagógica. Revista Brasileira de Ciências Do Esporte, 37(3), 289-298. doi: https://doi.org/10.1016/..rbce.2014.01.002

Freitas, Helena. (2003). Certificação Docente e formação do educador: regulação e desprofissionalização. Revista Educação e Sociedade, 24(85), 1095-1124. Recuperado de https://www.scielo.br/pdf/es/v24n85/a02v2485.pdf

Fröhlich, Marcelo Augusto. (2010). Políticas públicas de formação continuada de docentes: dos marcos legais à realidade de duas redes municipais de ensino do Rio Grande do Sul (Tese de Mestrado). Pontifícia Universidade Católica do Rio Grande do Sul, Brasil. Recuperado de http://tede2.pucrs.br/tede2/bitstream/tede/3641/1/422045.pdf

Gatti, Bernardete Angelina. (2010). Formação de professores no Brasil: características e problemas. Educação \& Sociedade, 31(113), 1355-1379. doi: https://doi.org/10.1590/S0101-73302010000400016

Gauthier, Clermont., Martineau, Stéphane., Desbiens, Jean- François., Malo, Annie., e Simard, Denis. (1998). Por uma Teoria da Pedagogia: pesquisas contemporâneas sobre o sabre docente. ljuí, Brasil: UNIJUÍ.

Günther, Maria Cecilia Camargo., e Molina Neto, Vicente. (2000). Formação permanente de professores de Educação Física na rede municipal de ensino de Porto Alegre: uma abordagem etnográfica. Revista Paulista de Educação Física, 14(1), 85-91. doi: https://doi.org/10.11606/issn.2594-5904.rpef.2000.138020

Hargreaves, Andy. (2002). Aprendendo a mudar: o ensino para além dos conteúdos e da padronização. Porto Alegre, Brasil: Artmed.

Heringer, Dionésio Anito., e Figueiredo, Zenólia. (2010). Práticas de formação continuada em 
Educação Física. Movimento: Revista de Educação Física da UFRGS, 15(4), 83-105. doi: https://doi.org/10.22456/1982-8918.6255

Herneck, Heloisa., e Mizukami, Maria da Graca. (2002). Desenvolvimento e aprendizagem profissional na docência: impacto de um programa de formação continuada. In A. M. Reali e M. Mizukami (Eds.), Formação de professores: práticas pedagógicas e escola (pp. 315-337). São Carlos, Brasil: EdUFSCar.

Huberman, Michel. (1995). O ciclo de vida profissional dos professores. In: A. Nóvoa (Org.), Vidas de professores (2⿺ ed.; pp.31-61). Portugal: Porto Editora.

Imbernón, Francisco. (2006). Formação continuada de professores. Porto Alegre, Brasil: Artmed.

Imbernón, Francisco. (2009). Formação permanente do professorado: novas tendências. São Paulo, Brasil: Cortez.

Imbernón, Francisco. (2011). Formação docente e profissional: formar-se para a mudança e a incerteza ( $9^{a}$ ed.). São Paulo, Brasil: Cortez.

Lakatos, Eva María., e Marconi, Marina de Andrade. (2003). Fundamentos de pesquisa metodológica científica. São Paulo, Brasil: Atlas. Recuperado de http://docente.ifrn.edu.br/olivianeta/disciplinas/copy of historia-i/historia-ii/china-eindia/view

Lapo, Flavinês Rebolo., e Bueno, Belmira Oliveira. (2003) Professores, desencanto com a profissão e abandono do magistério. Cadernos de Pesquisa, (118), 65 -88.

Lira, Núbia. (2015). Formação continuada dos professores de educação física da rede pública de ensino do município de aracaju: mediações do "programa horas de estudo (Tese apresentada ao Programa de PósGraduação). Universidade Federal de Sergipe, Brasil. Recuperado de https://ri.ufs.br/handle/riufs/4590

Loureiro, Walk., e Caparróz, Francisco Eduardo. (2011). Formação Continuada em Descontinuidade: politica de mandato ao inves de Politica de Estado. Meta Avaliação, 3(7). https://revistas.cesgranrio.org.br/index.php/metaavaliacao/article/view/104

Lüdke, Menga., e André, Marli. (1986). Pesquisa em educação: abordagens qualitativas. São Paulo, Brasil: Editora Pedagógica e Universitária.

Marcolino, Taís Quevedo., Lourenço, Gerusa Ferreira., e Reali, Aline. (2016). "Isso eu levo para a vida": aprendizagem da prática profissional em uma comunidade de prática. Interface - Comunicação, Saúde, Educação, 21(61), 1-11. doi: https://doi.org/10.1590/1807-57622016.0099

Marin, Elizara Carolina., Souza, Maristela Silva., Ribas, Joao Francisco., Decian, Marluce Raquel., e Herbst, Fabiane Rossato. (2011). Formação Continuada em Educação Física: Relação entre Mundo do Trabalho, Políticas Educacionais e Educação. Movimento: Revista de Educação Física da UFRGS, 17(2), 259-278. doi: 
https://doi.org/10.22456/1982-8918.16670

Maués, Olgaises Cabral. (2003). Reformas internacionais da educação e formação de professores. Cadernos de Pesquisa, (118), 89-118. doi: https://doi.org/10.1590/S010015742003000100005

Mendes, Cintia. (2008). HTPC: Hora de trabalho Perdido Coletivamente? (Tese do Mestrado). Universidade Estadual Paulista, Brasil. Recuperado de http://hdl.handle.net/11449/92388

Mizukami, Maria da Graca Nicoletti. (2002). Escola e aprendizagem da docência: processos de investigação e formação. São Carlos, Brasil: EdUFSCar.

Molina Neto, Vicente. (1997). A formação profissional em Educação Física e Esportes. Revista Brasileira de Ciências Do Esporte, 19(1), 34-41.

Moreira, Evando Carlos., Pereira, Raquel Stoilove., Lopes, Tomires., Santos, Eliane., Schüller, Juliana Aparecida., e Gomes, Cleomar. (2014). Proposta pedagógica para o ensino da Educação Física em Cuiabá: Relatos de uma formação continuada. Revista Eletrônica de Educação, 8(3), 278-290. doi: https://doi.org/10.14244/198271991049

Nóvoa, Antonio. (1995). Formação de Professores e profissão docente. In A. Nóvoa (Ed.), Os professores e sua formação (pp. 13-33). Lisboa: Dom Quixote.

Nóvoa, Antonio. (2019a). Entre a Formação e a Profissão: ensaio sobre o modo como nos tornamos professores. Currículo Sem Fronteiras, 19(1), 198-208. Recuperado de https://www.curriculosemfronteiras.org/vol19iss1articles/novoa.pdf

Nóvoa, Antonio. (2019b). Os Professores e a sua Formação num Tempo de Metamorfose da Escola. Educação \& Realidade, 44(3). doi: https://doi.org/10.1590/2175-623684910

Nóvoa, Antonio., Gandin, Luiz Armando., Icle, Gilberto., Farenzena, Nalu., e Rickes, Simone. (2011). Pesquisa em educação como processo dinâmico, aberto e imaginativo: uma entrevista com António Nóvoa. Educação \& Realidade, 36(2), 533-543. Recuperado de https://www.redalyc.org/pdf/3172/317227057004.pdf

Oliveira, Dalila. (2004). A reestruturação do trabalho docente: precarização e flexibilização. Revista Educação e Sociedade, 25(89), 1127-1144. Recuperado de https://www.scielo.br/pdf/es/v25n89/22614.pdf

Rossi, Fernanda. (2010). Formação continuada em educação física escolar: concepções e perspectivas de professores (Tese do Mestrado). Universidade Estadual Paulista "Júlio de Mesquita Filho", Brasil. Recuperado de http://hdl.handle.net/11449/96101

Rossi, Fernanda. (2013). Implicações da formação continuada na prática pedagógica do(a) professor(a) no âmbito da cultura corporal do movimento (Tese do doutorado). Universidade Estadual Paulista "Júlio de Mesquita Filho", Brasil. Recuperado de http://hdl.handle.net/11449/100445 
Rossi, Fernanda., e Hunger, Dagmar Aparecida. (2013). A formação continuada sob análise do professor escolar. São Paulo, Brasil: Editora UNESP. Recuperado de http://hdl.handle.net/11449/113712

Sampaio, Maria das Mercês., e Marin, Alda. (2004). Precarização do trabalho docente e seus efeitos sobre as práticas curriculares. Educação \& Sociedade, 25(89), 1203-1225. Recuperado de https://www.scielo.br/pdf/es/v25n89/22618

Sarti, Flavia. (2012). O triângulo da formação docente: seus jogadores e configurações. Educação e Pesquisa, 38(2), 323-338. doi: https://doi.org/10.1590/S1517$\underline{97022012000200004}$

Scheibe, Leda. (2010). Valorização e formação dos professores para a educação básica: questões desafiadoras para um novo plano nacional de educação. Educação \& Sociedade, 31(112), 981-1000. Recuperado de https://www.scielo.br/scielo.php?pid=S0101$\underline{73302010000300017 \& \text { script }=\text { sci abstract\&tlng=pt }}$

Schön, Donald. (1992). Formar professores como profissionais reflexivos. In: Os professores e sua formação (pp. 77-92). Lisboa, Portugal: Dom Quixote.

Schön, Donald. (2000). Educando o profissional reflexivo: um novo design para o ensino e a aprendizagem. Porto Alegre, Brasil: Artmed.

Silva, Mellissa. (2014). A prática como lócus de formação de professores e produção de saberes na Educação Física (Tese Doutorado). Universidade Estadual Paulista Júlio de Mesquita Filho, Brasil. https://repositorio.unesp.br/bitstream/handle/11449/126341/000841458.pdf?sequence= 1

Souza, Denise. (2006). Formação continuada de professores e fracasso escolar: problematizando o argumento da incompetência. Educação e Pesquisa, 32(3), 477-492. doi: https://doi.org/10.1590/S1517-97022006000300004

Souza, Gabriela. (2013). Horas de Trabalho Pedagógico Coletivo (HTPCs): espaços de formação contínua e de produção de saberes docentes? (Tese do Mestrado). Universidade Estadual Paulista, Brasil. Recuperado de https://repositorio.unesp.br/bitstream/handle/11449/92363/souza gr me prud.pdf?seq uence $=1$ \&isAllowed $=y$

Souza Neto, Samuel., Vedovatto Iza, Dijnane., e Da Silva, Mellisa. (2017). Aprendizagem da docência na socialização profissional em Educação Física. Motriz: Revista da Educação Física, 23(2). doi: http://dx.doi.org/10.1590/S1980-6574201700020008

Tardif, Maurice. (2012). Saberes docentes e formação profissional (13 $3^{\text {th }}$ ed.). Petrópolis, Brasil: Vozes.

Tardif, Maurice. (2013). A profissionalização do ensino passados trinta anos: dois passos para 
a frente, três para trás. Educação \& Sociedade, 34(123), 551-571. doi: https://doi.org/10.1590/S0101-73302013000200013

Tardif, Maurice., e Lessard, Claude. (2014). O trabalho docente: elementos para uma teoria da docência como profissão de interações humanas ( $9^{\text {th }}$ ed.). Petrópolis, Brasil: Vozes.

Tardif, Maurice., Lessard, Claude., e Gauthier, Clermont. (2001). Formação dos professores e contextos sociais. Porto, Portugal: Rés Formalpress.

Tardif, Maurice., e Moscoso, Javier. (2018). A noção de profissional reflexivo na educação: atualidades, usos e limites. Cadernos de Pesquisa, 48(168). doi: http://dx.doi.org/10.1590/198053145271

Teixeira, Eliara Cristina Nogueira da Silva. (2016) Impactos da lei do piso salarial nacional no município de Pindaí - Ba e suas implicações na valorização docente: sentidos dos/as professores/as (Dissertação de mestrado), Universidade Estadual do Sudoeste da Bahia, Vitória da Conquista, Bahía, Brasil. Recuperado de http://www2.uesb.br/ppg/ppged/wp-

content/uploads/2017/03/Disserta\%C3\%A7\%C3\%A3o-de-Mestrado-Eliara-CristinaNogueira-da-Silva-Teixeira.pdf

Veiga Simão, Ana Margarida., Flores, Maria Assuncao., Morgado, Jose Carlos., Forte, Ana Maria., e Almeida, Teresa Fragoso. (2009). Formação de Professores em contextos colaborativos. Um projecto de investigação em curso. Sísifo: Revista de Ciências Da Educação, (8), 61-74. Recuperado de http://centrorecursos.movimentoescolamoderna.pt/dt/3 2 formacao professores/32 22 fom prof cont colabortativos amvsimao.pdf

Wittorski, Richard., e Vieira, Denise. (2014). A contribuição da análise das práticas para a profissionalização dos professores. Cadernos de Pesquisa, 44(154), 894-911. doi: https://doi.org/10.1590/198053143039

Yin, Robert. (2015). Estudo de caso: Planejamento e métodos (5 ${ }^{\text {th }}$ ed.). Porto Alegre, Brasil: Bookmen. 
Revista indizada en
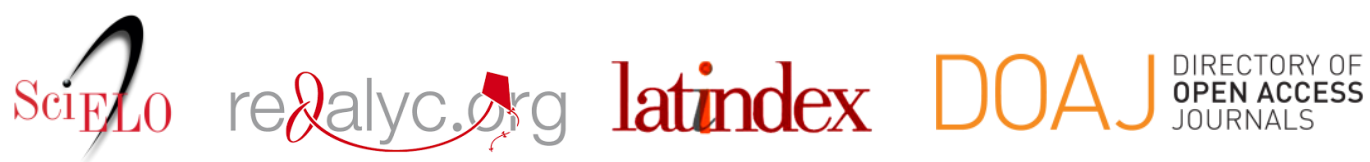

Distribuida en las bases de datos:

- Dialnet

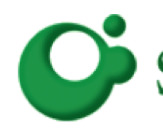
SHERPA/RoMEO

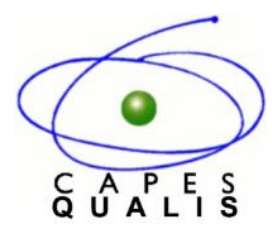

MIAR 
